\title{
Powers Languages, War Languages, Education and Literature: Two Ways of Seeing and Living the Forced Displacement Drama in Colombia
}

\author{
Miguel Alberto González González \\ Universidad Católica de Pereira, Pereira, Colombia
}

\begin{abstract}
This qualitative study has a look at how some literature Colombian writers address forced displacement, and at the same time, how teachers see that problem and the way they live, and solve their students forced displacement. This study also reviews some Colombian literature important books, those giving an account of the war and the impacts it has on education. In addition, some teachers are interviewed in order to know their view around the forced displacement problem. As for literature, displaced people drama is approached from many Colombian scenarios, even from education itself point of view, since education knows about displaced people problem and there is not a clear awareness to tackle the problem. In the end, Colombian war victims' number can reach several million, as the education system does not have enough elements to confront the problem. Therefore, this paper's main question is: How is forced displacement addressed by literature and which is education's place?
\end{abstract}

Keywords: voluntary displacement, forced displacement, migration, literary look, land ownership, exile, education, violence, war, displacement technologies, hatred, communities, peace

\section{How Is Migration Addressed Through Some Literary Narratives in Colombia? ${ }^{1}$}

For some reason, one that is not easy to understand, Colombia became an easy territory for the violent ones, a territory where displacing and leaving the peasants out of their lands became one of the greatest technologies, displacing technologies. For this purpose, far-right or far-left armies have been made, whose interest in exercising violence hides something more dramatic, seizing lands, regardless of human misery. It is not only moving, but also banishing, removing the lands and lives if necessary.

Colombian literature has mentioned something about it, such as writer Evelio Rosero in his novel Los Ejércitos, ${ }^{2}$ which has been fairly rewarded; highlighted the problem of migration, "I write to exorcise the pain of violence," explained Rosero (2010), then stated that, "I have talked to those displaced from Cali, where my mother lives. Their experiences fed part of my story. All anecdotes I narrate are real." No one can win a war with displaced people and rifles, and as land and power can be obtained, hatred is sowed and young are taught how to kill.

\footnotetext{
Miguel Alberto González González, Ph.D. in Education Science and Ph.D. in knowledge and culture of Latin America; professor and researcher, Faculty of Humanities, Social Sciences and Education, Universidad Católica de Pereira.

${ }^{1}$ This text comes from the research: Lenguajes de los poderes. Las homogeneizaciones/diversidades y las exclusiones/inclusiones en los sistemas Educativos Superior en Argentina, España, México, Chile, y Colombia. Diálogos de sabers (2014-2017).

2 The army.
} 
In the same sense, and from the Colombian writer Laura Restrepo's book Las multitudes Errantes, ${ }^{3}$ a look at the internal refugees of Colombia and internal migration is taken, which then ends up spreading to Ecuador, Venezuela, USA, and Spain. However, when it has to do with migration, not everything is a tragedy, as noted by Laura Restrepo, since love, hope, and encounters with others are also risen, where love, despite the negative imaginary, is possible in migrations. In a similar vein, the columnist Alfredo Molano, who has been committed to the understanding of Colombian war and displacement problems, brings us this look with his book Ahi les dejoesos fierros, ${ }^{4}$ where the word "fierros" ("irons" for English) is a euphemism for referring to weapons.

This is delving for an instituting passion, for a deep thinking, for a seminal thinking where migration is an act of violence, and a kind of dispossession. From these scriptures or from the biblical exodus itself, certain human persistence is confirmed, it is as if migration were humanity's greatest history having to displace because of a sort of powerful one commands it. Hence, the literature has been there to record humanity displacements, whether they are forced or not. From those gaits in The Bible or the ones in The Odyssey, to the novels Los Ejércitos y La multitud, there is something congregating us: people's migration; it is as if from the literature we were some eternal displaced ones, even from Paradise itself.

Education, as in many cases owes us answers, it looks pale and emaciated as mentioned by the same Colombia's Ministry of Education, it does not even have clear actions about it, and "at least $35 \%$ of the displaced adult population has not received any instruction." These data shows that the displaced one in Colombia suffers not only from expatriation or from loss of their land, their property, and their culture, but also receives indolence and indifference from the educational system. In Colombia, war is not wanted to be mentioned, war is lived and called through euphemisms: internal conflict, political struggles, actions of drug trafficking, social maladjustments, or to shade it more; terrorist groups' actions. However, almost everybody, both governments and society have denied war, and therefore, displacement is assigned a unique character of crime which is not related to the internal war, a war that despite much evidence, is not accepted in the governmental, academic and political imaginary. Furthermore, those who have certainly insisted in an existing war Colombia are educators and writers. Educators because they have endured it themselves from their own realities and the writers based on their daily experience and conversations with the actors involved in; both make us realize that we are living a war, despite presidents, military and other powers engaging on denying it.

Every time we are displaced, we are expel from the paradise. Thanks to the script, we know of the displaced, their hardships, and of course, their erotic. What or who promote migration in Colombia? Who are the owners of war, who ordered warfare? They are deep questions whose answers can not look only on the leaves of trees or books, we must go to the roots, to the same sources, because if anything is clear is that nobody wants to take over the war and its consequences, blame the other is the worst thing we can do, not seeking causes but guilty to detach it the real problem.

\section{The Tragedy of Being Displaced}

Being a displaced person by violence and armed opposition, it is a life-changing tragedy. If something fitsinto this discussion, it is when Socrates chose to die by drinking hemlock rather than the exile as a punishment. Exile is as infamous as kidnapping, torture, or murder, one being banished and running out of a

\footnotetext{
3 The wandering crowds.

4 Here, I leave these irons, this guns.

5 Retrieved April 27, 2015, from http://www.mineducacion.gov.co/1621/article-87379.html.
} 
land, without a homeland. A drifter, a displaced one is not someone finding another place on a whim, although it may be possible. But in the case of Colombia, wandering in the background, getting deep into the problem and the soul, it is merely a life safe guarding for the death not to reach us without having lived long enough. Restrepo (2001, p. 14) wrote, "I wanted to know if a recasting woman in the traffic of war had passed around here." Traffic, transits of the Colombian war have recast people and hopes, not just women, of course; but men and children. What is complex, is that even in the second decade of the third millennium, armed conflict people recasting is still happening; a conflict that has won nothing in 50 years, but if it has buried tons of lives, tons of dreams, whilst displaces more than 5 million Colombians. In fact, Colombia is the nation having more refugees in the world.

Colombian newspapers make a constant echo from internal and external displacement, from those violent acts that force thousands of people to migrate and walk aimlessly. The next information makes the situation clearer, "Some 4.9 million people were internally displaced in Colombia from 1985 to 2009," said the Human Rights Consultancy representative (CODHES), who together with the Colombian Episcopal Conference have monitored forced displacement for two decades. ${ }^{6}$ It is not just Matilde Lina in the Laura Restrepo's novel $L a$ multitude Errante, who keeps on living. It is also those millions of displaced ${ }^{7}$ and their families wanting to know about them, whether they are in distant lands or else, because they have already been disappeared. They are ghosts, they are dead or even worse, they were murdered and disappeared, by establishing tombs in the jungle, in therivers or in the air, as it was the case of the Nazi Holocaust, which has also been imitated in Colombia. ${ }^{8}$

In La multitude Errante, everything is a memory, everything is nostalgic, everything is confusing, but memories come with some clarity, i.e., when the memories themselves can reconnect with the horror clarity. Restrepo (2001, p. 11) stated that, "I buried my husband and three of my children, and then I ran away with what they had left me." This story from one of the La multitude Errante characters, gives us an approach to the last 50 years of pain in Colombia. Women watching their children and husband dying, women rebuilding their lives after many atrocities, women remaking their lives in other lands where that history is bound to be repeated later, i.e., to see their loved ones dying or beyond that facing their own death. The partisan war in Colombia was lived to the extremes, but also taught us to live around them. Being a liberal or a conservative one, a red or a blue, blue ones from the church and the redones from the devil. Restrepo (2001, p. 31) stated that, "Conservatives painted all the small town doors in blue; even cows and donkeys were painted in blue, and it was said that he who dares to walk around in red clothes, would have his throat cut... looking at this hopeless case, the red ones from Santamaría said goodbye to their land, by watching it from alast time." This story questions us, since something else was hidden in this partisan struggle, i.e., murdering, forcing wandering to seize the land and to seize political power in the region. Restrepo (2001, p. 31) stated that, "The blue ones say they will only stop when the entire liberal ones blood is spilled. They also say this is how they think on winning next elections." There is no doubt that killing is not just because of hatred, but also for political expediency.

The story beginning with the killings and displacements after Jorge Eliecer Gaitan's death on April 9, 1948 , seems to be a description or a re-edition of what happened in the 1990s and even in the XXI century

\footnotetext{
${ }^{6}$ Retrieved April 28, 2015, from http://www.elespectador.com/articulo-234028-colombia-registra-49-millones-de-desplazados -conflicto-armado.

7 Retrieved April 28, 2015, from http://www.elespectador.com/noticias/paz/unos-3700-afectados-conflicto-armado-colombiano -viven-e-articulo-555307.

${ }^{8}$ Retrieved May 2, 2015, from http://desentranando-colombia.periodismohumano.com/2010/06/10/descuartizamientos-y-hornoscrematorios/.
} 
second decade, the horror of abandoning lands because of mass killings. Restrepo (2001, p. 32) stated that, "Here and there, piles of liberals who also wandered adrift were being incorporated; newly displaced by evictions and killings; more survivors from villages and devastated fields." These 1950s pilgrimages look alike current displacement, then, liberals and conservatives, and guerrillas, paramilitaries, and soldiers nowadays. Beyond that, they both do the same: benefiting someone, someone who buys lands or just keep them for himself, finally, nobody will ever claim them.

Since the 1990s, syndicating and pointing are laws, one is judged from being an extreme leftist or rightist, pro-government, or simply being neutral. Restrepo (2001, p. 73) stated that, "He looked at his new shoes with an unfathomable sadness, then, he began to untie the laces with the resignation of a condemned man stretching his neck towards the edge of the ax." Just a comment, a friendship, a letter, or a look can be assessed for adeath sentence.

To seek a shelter when one is a displaced person is another Odyssey, as supports are temporary and one is just a nuisance everywhere. All a displaced one knows is that nobody wants them neither from where they were banished, nor where they arrive. Restrepo $(2001$, p. 88 ) stated that, "No one arriving here stays forever; this is just a way station offering no future. We provide displaced ones with a roof, shelter, and food for 5 or 6 months while they overcome the tragedy and return to be a person", says one of the displaced people shelter leaders. Being banished is to take upon oneself a strange sentence; is to begin cultivating hatred and to build possible retaliations.

For a displaced one, even love is displaced, Restrepo (2001, p. 93) stated that, "I do not think it is a prudent thing falling in lovewitha displaced one," says the shelter nun. Such are the realities of boarder displaced people but is similar to those suffered by the ones who migrate from Colombia to the United States or Europe, a few want them and a few believe in them as to be innocent ones.

Leaving the place where you have everything is like abandoning paradise. Adam must have felt something similar according to the biblical narrative, expect that he did not have to endure the death of his neighbors or his own family. Restrepo (2001, p. 103) stated that, "In less than two weeks, the rash of crimes that devastated the area had left twenty people executed." In Colombia, it is turned around assassination technologies, then constituting them into displacing technologies.

Violence against women records scandalous statistics, Colombia has known about women as born for reproduction, sex objects, or war trophies. "A pregnant 18 years old girl was stuck with astick through her genitals and taken it all the way up. Then, she was dismembered. [...] Women were gotten naked and forced them to dance in front of their husbands. Several were raped. From a ranch near 'El Salado' [Department of Bolívar] screams were heard." As such stories, writing son how women have suffered from this war abound in Colombian; thus, if anybody comes out alive, he opts for exile.

\section{Forced Displacement, Displacement for Iands, and Displacing Technologies}

There is obviously people and lands displacement under adverse pretexts. Besides, there is a displacing technology inside, an entire industry. About forced displacement for land dispossession in Colombia, the United Nations High Commissioner for Refugees (UNHCR) stated that, "Up to May 2011, the Agencia Presidencial para la Acción Social (the Presidential Agency for Social Action), a government organism that coordinates the displacement policy—has registered nearly 3.7 million people who have been forcibly displaced from their homes. Nearly $70 \%$ out of them had ties to the lands, as owners, holders, tenures, or 
occupiers". ${ }^{9}$ Moreover, the problem of land tenure has not been discussed in the country. In fact, those who settle outside of a property looking for a small 60 square meters space or less to build their own home, are called invaders, and then, forced out to leave by public force losing their few belongings and starting a new pilgrimage, a new walk, or a new displacement.

In the following book story Los Ejércitos, we are put in tension, in front of violence forcing many people to move within the country and even to flee out of it for the rest of their lives before falling down dead in another attack. Rosero (2010, p. 12) stated that, "Early an orphan, her parents had died when a last attack happened in our village, still unknown from who or where. Was it the paramilitaries, the guerrillas? A barrel of dynamite exploded in the middle of the church, at the time of the elevation with half of the village's people inside. It was the first mass on Maundy Thursday, and there were 14 dead and 64 injured people." As this paragraph moves forward, we, those ones who live in Colombia know this is true, no matter whether we identify the people or the church. What we do not really doubt is that this actually occurred, not only once but many times, and paradoxically, it can happen again. ${ }^{10}$

In a report published in 2004 by Amnesty International, it is highlighted that, "During the past 20 years, the internal armed conflict in Colombia has claimed the lives of at least 70,000 people, most of them civilians killed out of combat." Tens of thousands have been abducted, "disappeared and tortured, and more than three million have been forced to abandon their homes". "While there are not agreements in numbers, some others have even written that there have been nearly 150,000 people killed during the past 30 years."

When it has to do with displacing and murder technologies, not only outside the law groups have participated, likewise, Colombian armed forces have taken their days of darkness, their nefarious moments as recorded in its most recent and painful experience, called "false positives." When reviewing books and reports, there is a coincidence of abuse having its highest degradation since 2002 during Uribe's government, those disastrous actions still occurring. As shown in many reports "by the Colombia-Europe-United States Coordination, there are 5,700 formal complaints and Attorney's Office is currently carrying out 3,430 inquiries on these facts". ${ }^{12}$ These actions accelerate and force displacement.

\section{Displaced Children from Education and Integrated to War}

Because of violence in Colombia, many systems have mutated, in fact, the murderers, who make up the armies, have had murderous experience. Many have been assassins since they were young or even since they were children. Rosero (2010, p. 12) stated that, "His eyes made me think he was going to shoot me until he ran out of bullets. And that is when I discovered the murderer was a young man; he must have been 11 or 12 years old. He was a child." This job is learnt soon, first to murder, then to kidnap, and finally, to banish anyone who is presumed to be dangerous. These children do not return to school and quit their learning processes to join the war, whereas education has neither real supporting tools nor the state help to prevent this to continue happening.

Non-thought deaths, unintended deaths are other sort of tragedies as those caused bystray bullets, and this is paradoxically true, sincethey usually target someone in its way. Rosero $(2010$, p. 32) stated that, "I was not

\footnotetext{
9 Retrieved April 15, 2015, from http://www.acnur.org/t3/operaciones/situacion-colombia/desplazamiento-interno-en-colombia/.

10 Hechos de violencia de conflicto armado interno en Colombia. (2014). Retrieved April 16, 2015, from http://es.wikipedia.org/wiki/Anexo:Hechos_de_violencia_del_conflicto_armado_interno_en_Colombia.

${ }_{11}$ Retrieved May 4, 2015, from http://www.dw.de/ai-guerra-sucia-contra-el-sindicalismo-en-colombia/a-2668485.

12 Retrieved May 30, 2015, from http://www.verdadabierta.com/especiales-v/2015/falsos-positivos/\#sthash.BbO1mxqy.dpuf.
} 
even 20 yet when it killed him on a corner, a stray bullet, without any evidence ofthe who, where or how." This is quite common in Colombia, where a stray bullet kills children who are studying. ${ }^{13}$ Justice rarely identifies the shooters because justice is as stray as the murderous bullets. In Colombia, there are thousands of deaths caused by stray bullets. ${ }^{14}$

There is also this children tragedy in Colombia's war. As Rosero (2010, p. 35) uttered, "They killed a newborn and then made the sign of the cross: She was dismembered. There is no God." When murderers do not find a targeted adult, they decide to kill their son or daughter as a warning. Furthermore, killed children are not even register in local education systems. Children who have been forcibly displaced between 1985 and 2012 have reached the appalling number of two and a half million. ${ }^{15}$

What is more, illicit armed groups have copied compulsory military service, as all of them need people who wield guns to kill, kidnap, or defend an unknown homeland, honor, or commander. Children being part of armed groups reach incredible numbers, thus, all of them must quitthe education system and paradoxically learning the terrible art of murdering and kidnapping. Childhood international tribunal states that between 14,000 and 17,000 children integrate Colombian illegal armed groups. ${ }^{16}$

Landmines, those sown by the armies leave thousands of victims and many are children who step into them as they go to school, Rosero (2010, p. 68) stated that, "Again, other anti-personnel mines have exploded, or are heard.... We seem to be besieged by an invisible army, and hence, a very effective one." The same, there are villages besieged by mines planted by armed groups in their surroundings.

Landmines victims are thousands, where students and teachers are killed in minefields. "Out of the total casualties reported in the period 1990 to March 31, 2015, 8,879 (80\%) were injured and 2,218 (20\%) died in the accident place. Similarly, 4,251 of these victims are civilian population, from which $3,444(81 \%)$ were injured and $807(19 \%)$ died. As for the 6,846 security forces members casualties, 5,435 (79\%) were injured and $1,411(21 \%)$ died". ${ }^{17}$ Victims' numbers are dreadful; and the pride of war over educational options shows us the level of brutality being reached.

In addition, without a help, a government, or a property, decimated by the deaths of their relatives or neighbors and reduced by the armed harassment. Displaced people along with their children leave without return. They not only abandon their lands, but also leave the possibilities of being educated. Rosero (2010, $\mathrm{p}$. 190) stated that, "At about the school high, I run into a group of people walking in a row towards the road. They are leaving San José: They must have thought the same as me; they are a huge piece of town that leaves." This explains what is more than 5 million internally displaced and more than 5 million Colombians living in austere conditions in the United States or Europe. Furthermore, a few others are still treated as third class citizens and accused of being drug dealers or anything else related to this. Nobody wants them, and as their homeland forces them to leave, they are unwelcomed where they arrive. Henceforth, why is it worth it to have a homeland? Hatred is learned, and then taught, and after such contempt, what else can come about?

\footnotetext{
13 Retrieved April 30, 2015, from http://www.eltiempo.com/archivo/documento/CMS-12711547.

14 Retrieved April 31, 2015, from http://www.eltiempo.com/archivo/documento/CMS-8735940.

15 Retrieved May 3, 2015, from http://www.eltiempo.com/colombia/otras-ciudades/ninos-y-jovenes-las-peores-victimas-delconflicto-armado-colombiano/15602838.

${ }_{16}$ Retrieved May 5, 2015, from http://www.elespectador.com/noticias/politica/cifras-sobre-los-ninos-y-guerra-articulo-555062.

17 Retrieved May 5, 2015, from http://www.accioncontraminas.gov.co/estadisticas/Paginas/victimas-minas-antipersonal.aspx.
} 


\section{What About Education?}

Education in Colombian has not address this issue in depth, and sometimes neither understands its magnitude. This is not about judging education, but it is worth it asking it why the displaced people problem is muted in the classroom, and why violence is so cruelly imposed in Colombian territory as intellectuals are silenced. The fact is that there are not programs for displaced families in the education processes that respond to their changing needs. There is so much blindness and deafness into educational programs that infants may fail their school years because of that forced absenteeism. Colombian education is deaf, blind, and indolent before the dramas of the displaced ones. After all this, what is next for the people, for a country, for their communities? Rosero (2010, p. 133) responded that, "Professor, why do not you come with us, with our families?" It is about time to wander around the world, to leave as a displaced one through the lands telling his miseries, recounting his pains, along with other wandering communities, then perhaps, the armies themselves that afterwards will weep and walk their own pains with their own abandonments and exiles.

Education? That of the landless owners, that of the lost dreams, that of the hunger and sadness, of the desolation and despair. Colombia is a country that has plunged into the tyranny of the strongest, of the hidden euphemisms, of the education inpieces. Where students protest and are not allowed talking, and if they dare to, some agreements must be made or else they are to be displaced. What is free education about whilst it is paid with blood, iniquity, inequality, and death? When are we going to have a concerned in displaced dramas education? The latter, to not teach and multiply the hatred, for not being another link in the chain.

Hatred is taught; and forcing to displace is another link in the chain. Through violence, killing is taught, and such is the word with no euphemisms, as murderers' schools. Molano $(2009$, p. 11) stated that, "I was sent to execute a guerrilla woman who had refused to collaborate, she was detected when sending a remittance in a cooperative store from our own which nobody knew... the 'bachiller' gave an order, to take her to her death... then he told me: learn how to do it." This is a kind of typical ritual, a kind of blood civic consecration; I become greater when facing the blood that I shed. As writing is made and domestic products are manufactured, so men and women are manufactured to hate, to murder, and then they will force others to abandon their lands, with their children, those who will have to break down their dreams of been somebody going to school.

It is curious, but a young person integrated to war feels like being naked without weapons, Molano (2009, p. 11) stated that, "When you get used to walk armed, then being without arms is like posing nude." This way, ideas do not work against a rifle, there is power behind a gun, also money, liquor, sex, and lots of fear to spread; that is why is not believed in the peace, because it is treacherous, Molano (2009, p. 22) stated that, "Peace agreements have brought more dead than the combats." War is a big factory to damage hearts, to make humans back to the wild.

Colombian memories seen from the known writers Eustasio Rivera, Cepeda Zamudio, García Márquez, Abad Faciolince, and William Ospina; are those where it has been immersed in a long social and moral disaster period. Political authorities' corruption and the desperate struggles for power have plunged this country into wars and massacres not yet concluded. All these writers have stressed the need to inherit Colombia within the reach of children, where studying is not a privilege but a reality, where forced people abandoning their lands, their memories, and their dreams, is not repeated.

In Colombia, there is no place for middle options, either you are a liberal one or a conservative, military, paramilitary, or guerrilla, and thus, some population blend in certain violence rituals. Then, Molano (2009, p. 
180) utterd, "I had all the violence stuck in the head," and the writer Fernando Vallejo warns us: Surrealism poorly crashes and smash into pieces against Colombia's reality.

Dead people in general are the poor ones: (a) foot guerrillas, paramilitaries, and privates; (b) foot peasants; and (c) foot poor people, all without a lineage, with atavistic hatreds and experts in killing the enemy. Because a country that does not know about forgiveness or making peace, a country which does not know how to educate their children, i.e., a country that knows a lot about wars, deaths, displacement, hatred, and forgetfulness, and even wanting to forget that people want to live in peace.

\section{Conclusions}

To rescue people's memory, not allowing them forgetting these terrible events, such as displacement and killings that came from the war, it is necessary to keep all possible forms to evoke them, such as films, novels, poetry, paintings, essays, or their own life stories.

From the novels, from these stories we have already found something that has been common in the Colombian news, i.e., extortion, kidnapping, assaults to population, landmines, raping, friendly fire, collateral damage, disappearing, exile, or displacements.

Colombians Caravans going from town to town, from village to village, and from country to country requesting a nursing home or a shelter that accepts them, that receives them without any constraints, because when someone has been displaced and between multiple humiliations delivered, there are two inviolable conditions: never to return nor to sue.

Furthermore, when calling it the 1950s partisan violence, i.e., liberals against conservatives, or vice versa, guerrilla violence, paramilitary violence, state violence, or drug violence. In any case, what they have left are graves on the roads, improvised cemeteries, crematoria Nazi-style, and millions of displaced people whose lands nobody knows or suspect whom they belong. In the end, no one dares to speak.

From this Colombian tragedy, some love have emerged, some havens have flourished. However, the great pain, the self-controlled cry still lives among Colombian population, hence, 5 million internal displaced people and 5 million immigrants living in Europe, Japan, the United States, or other countries in Latin America, are making their lives by pushing and rebuilding it, after the state oblivion. This tells us something about a country that does not want or protect its people, an indolent country having a disinterested in these misfortunes education.

Likewise, neither there are state policies to repatriate immigrants; nor they are credible to restore lands and ensuring peasants who lost them or their descendants keep them back. The current land restitution law is inadequate; it is even labeled as a failure by many important Colombian politicians. ${ }^{18}$

Colombian education has not stepped in the shoes of anybody, and less in displaced people shoes. The curricula, spaces, and teachers have the same routines for the whole community, which is reported in the literature, newspapers, and the same voices in the streets. The only rights immigrants coming in and out of the country have, is to keep running, or to take upon himself the pain of losing their own territories. Colombian population needs a culture of peace that it is built with dialogue, with total commitment, passion, and calm. In addition, from the teachers' job to address the problem, where the problem itself and the solution are contextualized, otherwise, the country will continue as it is now, having humans migrating forcefully against indifferent justice and education.

\footnotetext{
18 Retrieved May 5, 2015, from http://www.senado.gov.co/sala-de-prensa/noticias/item/17816-rotundo-fracaso-de-la-politica-derestitucion-de-tierras-de-santos-anuncia-senador-robledo.
} 
Justice looks indifferent, González (2010, p. 65) stated that, "Of course, a skinny justice in action: but an opulent in rules that does not solve urgencies with mere codes or quotations. In a dependent and little autonomous continent that does not care about justice, space to revenge and to self-righteousness is given, and therefore, self-defense groups and social cleansing bands, even subversive forces seeking to provide equal alternatives emerge." The ideals of equality are congested, diluted in a few days, and then, some poor and redemptive groups become pragmatic and wealthy, that is why they have a war machine available to make displacement a great technology, feeding their powers are interests, not those libertarian ones but the sectarian and precarious.

Undoubtedly, as González (2015, p. 61) said, "Local violence somehow, is based on the great social violence. Colombian violence is part of the global violence and the universal violence, as a product of Western civilization barbarism." Any human action affects other latitudes. In that sense, Colombians also have to learn from other successful experiences on education to confront the aftermath of a war.

War in Colombia is not an innocent one because of its displaced people, exile and massacres, war is more than an abstraction. It is not the continuation of politics through other means; it is simpler but more dramatic: It is an unidentified disease, because we have always denied it and politicians have been commissioned to make us believe we are democratic and liberal; whereas population is killed in the name of freedom, as well as displaced on behalf of inclusion, diversity, and multiculturalism. We are so perverse to the point that we hide and then deny it, as displaced people watch and listen to us in the streets, squares, school routes, and of course, in different corners of the country. Lastly, inside and out of Colombia forced displaced people drama continues, as well as that from the young ones who want to study, and then again, war breaking their dreams is being kept as an answer power still gives to them.

Colombian writers have tackled the problem of violence from many sides, in terms of forced displacement, García Márquez, Nobel Prize for Literature, in his great book One Hundred Years of Solitude creates the town of Macondo from a displaced group. This shows that the displacement in Colombia is not cujuntural, but structural issue. Human movements within Colombian geography are waves caused by armed groups, by political irresponsibility, and neglect of the state.

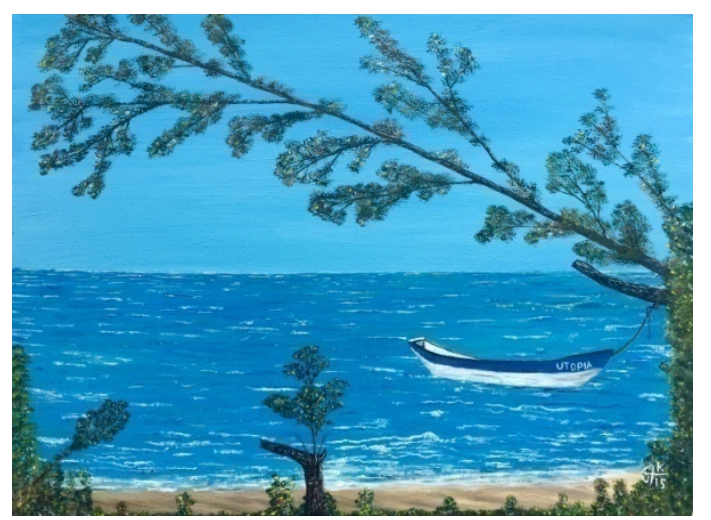

Figure 1. Colombia's displaced people suffer as displaced from Africa seeking other options in life. (Source: González González, 2015)

Being a displaced by violence, it is to be a subject that is adrift, a subject that is denied their own utopias. As the sea waves, well it behaved Colombian violence. Waves of murders, waves of hatred, and waves of armed men of the army and police fighting for a country that does not feel, for a country that turns its back, for 
a country that accuses them of being criminals; waves of armed guerrillas killing, kidnapping and doing justice with his own hands; waves of armed paramilitaries murdering, raping, kidnapping, and drug trafficking living; missing persons waves, waves of displaced humans, waves of women raped, humiliated waves of people, waves of cemeteries, and waves of wounds recover. But at the very end, almost at the end of tunnel, tunnel that has not been built quite right; born a small wave of change, winds of hope for displaced.

\section{References}

Abad, C. J. (2004). Colombia Cuerpos marcados, crimenes silenciados (Colombia scarred bodies, hidden crimes). Madrid: Editorial Aministía Internacional.

Agudelo, S. F. (2003). Momento y contexto de la violencia en colombia (Moment and context of violence in Colombia). Bogotá: Universidad Nacional de Colombia. Rev Cubana Salud Pública, 29(1), 18-36.

Al Tablero. (2012). Educación para desplazados un derecho, un deber (Education for displaced a right, a duty). Retrieved January 29, 2012, from http://www.mineducacion.gov.co/1621/article-87379.html

Cepeda Zamudio, A. (1998). La casa grande (The big house). Bogotá, Editorial Plaza y Janes.

Falsos Positivos. (2015). Una herida que sigue abierta (A wound that is still open). Retrieved May 30, 2015, from $\mathrm{http} / / /$ www.verdadabierta.com/especiales-v/2015/falsos-positivos/\#sthash.BbO1mxqy.dpuf

García Márquez, G. (1990). CienAños de soledad (One hundred years of solitude). Bogotá: Círculo de Lectores.

González González, M. A. (2010). Umbrales de Indolencia. Educación sombría y justicia indifente (Indolence thresholds: Dark education and in different justice). Manizales: Editorial Universidad de Manizales.

González González, M. A. (2014). Miedos y olvidos pedagógicos (Pedagogical fears and forgetfulness). Rosario, Argentina: Homosapiens y Universdiad católica de Pereira. Retrieved from http://www.researchgate.net/publication/270341600_Miedos y_olvidos_pedaggicos

González González, M. A. (2014-2017). Lenguajes de los poderes. Las homogeneizaciones/diversidades y las exclusiones/inclusiones en los sistemas Educativos Superior en Argentina, España, México, Chile, y Colombia. Diálogos de sabers (Languages of powers: The homogenizing/diversities and exclusions/inclusions in higher education systems in Argentina, Spain, Mexico, Chile, and Colombia. Dialogues of knowledge). Pereira: Univesidad Católica de Pereira.

González González, M. A. (2015). Learning in violent contexts. Dialogues war. Garujaj: Global Journal for Research Analysis, 4(3), 61-66. Retrieved from http://www.researchgate.net/publication/274251122_Learning_in_violent_contexts. Dialogues_war

González González, M. A. (2015). Oleadas (Waves). Oil on canvas. Pereira: Pereira.

González González, M. A. (2015). Tiempos intoxicados en sociedades agendadas (Intoxicated times in scheduled societies). Bogotá: Ediciones Desde Abajo.

Hechos de violencia de conflicto armado interno en Colombia (Violence of internal armed conflict in Colombia). (2014). Retrieved April 16, 2015, from from http://es.wikipedia.org/wiki/Anexo:Hechos_de_violencia_del_conflicto_armado_ interno_en_Colombia

Kant, I. (1795). La paz perpetua (Perpetual peace). Retrieved from http://www.biblioteca.org.ar/libros/89929.pdf

Mejía Rivera, O, A. (2000). Pensamientos de guerra (Thoughts of war). Manizales: Universidad de Caldas.

Molano, A. (2005). Desterrados, Crónicas del desarraigo (Exiles, chronicles of uprooting). Bogotá: El AncoraEditores.

Molano, A. (2009). Ahi les dejo esos fierros (Here, I leave the seirons). Bogotá: El ÁncoraEditores.

Reati, F. S. (2013). Pensamientos de guerra thoughts of war by Orlando Mejía Rivera: ¿Cómo nombrar lo indecible de la violencia colombiana? (Thoughts of war by Orlando Mejía Rivera: How unspeakable name of Colombian violence?) Retrieved 2013, from http://www.colombianistas.org/Portals/0/Revista/REC-32/4.REC_32_FernandoReati.pdf

Restrepo, L. (2001). La multitud errante (The crowd errant). Bogotá: Punto de lectura.

Rivera, J. E. (1997). La vorágine (The vortex). Bogotá: Círculo de Lectores.

Rosero, E. (2010). Los ejércitos (Thearmy) (2nd ed.). Barcelona: Tusquets Editores.

Vallejo, F. (1998). La virgen de los sicarios (The lady of the assassins). Bogotá: Alfaguara. 